\title{
Analysis and Countermeasures of Rural Land and Population Structure Change in Economic and Social Development
}

\author{
Yiqiao $\mathrm{Luo}^{1 *}$, Shengzhi Zhou ${ }^{2}$, Dan $\mathrm{Luo}^{3}$, Lingbo $\mathrm{Luo}^{4}$ \\ ${ }^{1}$ Chenzhou No.3 Middle School, Chenzhou, Hunan 423000, China \\ ${ }^{2}$ Huazhong University of Science and Technology, Wuhan, Hubei 430000, China \\ ${ }^{3}$ Hunan University of Technology and Business, Changsha, Hunan 410000, China \\ ${ }^{2}$ Tongshenghu Experimental School, Changsha, Hunan 410000, China \\ *Corresponding author. Email: $1493834001 @ q q . c o m$
}

\begin{abstract}
The development of rural economy and the overall progress of China's economy have a significant impact, so it is of great practical significance to analyze the current situation and influencing factors of rural economic development. From the analysis of data at this stage, rural economy is closely related to the changes of rural land and rural population. Therefore, on the basis of the relevant discussion on the rural economy, studying the related problems of the changes in rural land and population structure can more comprehensively find the specific problems in the rural economic development practice at the emerging stage. On the basis of the problems, emphasizing the formulation and implementation of countermeasures, the practical effect of rural economic development will be better. Based on the economic and social development, this paper analyzes the problems of rural land and population structure change, and discusses the coping strategies, aiming to provide guidance and help for practical work.
\end{abstract}

Keywords: Rural land, population structure, problems, coping strategies

\section{INTRODUCTION}

\subsection{Background of Topic Selection}

The problems of agriculture, rural areas and farmers are the major problems that must be solved in China's economic and social development. From the historical process of Chinese revolution, construction and reform and opening up under the leadership of the Communist Party of China, the problem of farmers in agricultural and rural areas is one of the main social problems that the Communist Party of China has been striving to solve. The success of the new democratic revolution was achieved with the broad participation and help of the broad masses of farmers; the establishment of a complete and independent socialist industrial system was realized on the basis of agricultural accumulation and great contributions made by farmers; after entering the new historical period, China's reform and opening-up began from the countryside. While the farmers' rural areas supported the construction of industrial cities and achieved prosperity, there was also a great imbalance between rural and urban development. "The level of rural productivity is very low", "the life of farmers is very hard" and "the ability to expand reproduction is very weak". This situation has been greatly improved today, but the problems faced by the development of agriculture and rural areas and the improvement of rural people's livelihood are still very serious.

In recent years, the CPC Central Committee has put forward a series of new policies and strategies to promote the development of agricultural and rural farmers based on the new changes of external environment and the new characteristics of the "three rural" issues. New vitality has emerged in promoting agricultural production, increasing farmers' income, protecting and improving ecological environment, which creates favorable conditions for promoting the harmonious development of China's economy and society and realizing the modernization of national governance system. However, it must be made clear that for the current China, the main social contradictions between the people's growing need for a better life and unbalanced and inadequate development are mainly manifested in unbalanced urban and rural development, inadequate agricultural development, and the need for further improvement in rural people's livelihood. In the new era of China's reform and opening up, promoting new urbanization, rural comprehensive revitalization, urban and rural integrated development has become the historical mission of the whole Party and the whole country. Reviewing the development process of China's rural reform and grasping the adjustment and improvement of agricultural and rural reform policies are conducive to summing up successful experiences, drawing lessons from mistakes, and accelerating the process of agricultural and rural modernization [1]. 


\subsection{Research Content}

After entering the 21st century, China's urbanization level is developing at a high speed, while the countryside is declining. Although the government has put forward a series of policies and measures, the three rural issues still fall into the paradox of sustained high attention and longterm serious problems. China's urban-rural dual structure has not been fundamentally changed, and the trend of widening urban-rural development gap has not been fundamentally reversed. The dual structure of urban and rural areas and the government policy biased by the city have resulted in the attraction and grabbing of rural labor force, capital, land and other elements by the cities and towns, making the rural productivity and means of production increasingly scarce, seriously restricting the development of rural areas.

Rural economic development is related to the overall progress of China's economy, so it is very necessary to emphasize the development of rural economy. The analysis of the current rural development practice will find that there are obvious changes in rural land use and population structure, which has affected the overall development of rural economy. Therefore, it is of great practical value to adopt targeted coping strategies according to the specific changes in rural areas. Only by clarifying the problems in rural development can we solve the problem of inadequate rural development and realize rural revitalization. Generally speaking, analyzing and discussing the specific changes and solving the specific problems brought about by the changes are of great significance to the stability and sustainable development of rural economy, and also have significant practical value for the balanced development of social economy.

\section{THE CHANGE OF RURAL LAND AND POPULATION IN CHINA}

From the specific analysis at this stage, the rural land and population have undergone obvious changes, and on the basis of this change, there are many problems. Summing up the specific changes and problems has prominent practical value in the analysis of rural development.

\subsection{The Change of Rural land and population}

In terms of rural land change, there are mainly two aspects: 1) the increase or decrease of rural land area. In rural areas far away from the city, in order to obtain more crops, farmers will reclaim some of the original wasteland, grassland, marshland, saline alkali land and so on into cultivated land, so as to increase the planting area. From the reality analysis, this situation has a positive effect on increasing farmers' income. In the rural areas near the city, the rural land has been reduced. From the practical analysis, the main reason for this situation is that more rural land is occupied by production and construction.
2) There is wasteland in the countryside. The so-called wasteland refers to the cultivated land with relatively good fertility, but in recent years, it has been uncultivated. This kind of situation is more common in the suburban rural areas, especially in the rapidly developing big cities.

The development of cities and towns must be accompanied by the increase of urban population and urban space area, and the expansion of cities and towns will occupy agricultural land. China's traditional urban construction is committed to the construction of infrastructure projects and the expansion of urban built-up area. The urbanization of land is faster than that of population. This way of urbanization not only reduces the quality of urbanization, but also reduces the area of Rural Cultivated Land and increases the risk of food security. According to the data in Figure 1, China's cultivated land area at the end of 2009 was 135.3846 million hectares. With the passage of time, by the end of 2016, China's cultivated land area was 134.9209 million hectares, and the cultivated land area decreased by 463700 hectares, with an average annual decrease of 58000 hectares [2-3].

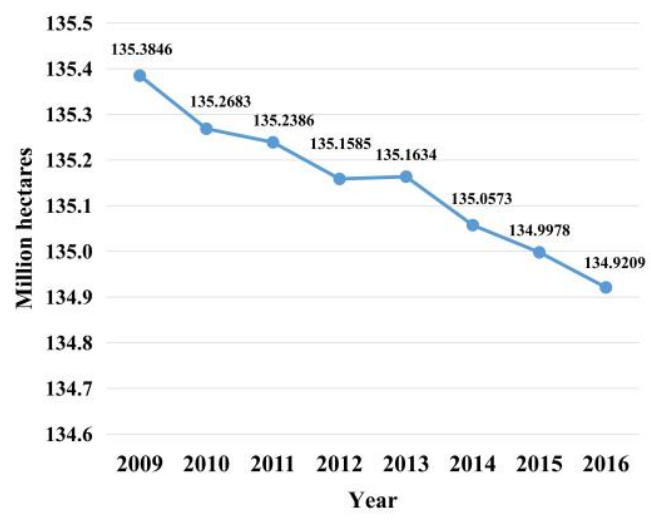

Figure 1. The change of rural cultivated land area

In terms of population structure, with the one-way flow of huge rural population to cities and towns, the rural population structure has changed, resulting in a serious "aging" of the village population in the outflow area, the rapid decline of the quality of rural grass-roots population, the serious lack of rural life, and the increasingly obvious trend of "hollowing out" of human capital, which has become a prominent limiting factor of rural development. The main trend of the change is that the proportion of the rural young and middle-aged population is decreasing year by year, while the proportion of the elderly is increasing. As an important endowment of economic development, human capital determines the effective use of material resources. The reserve scale of rural human capital is an important basis for the realization of agricultural industrialization and agricultural modernization. Figure 2 shows that the total number of agricultural production and operation personnel in China is 314.22 million, including 60.23 million people aged 35 years or below, accounting for $19.2 \%$ of the total number of agricultural production and operation personnel, 148.48 million people aged 
between 36 and 54 years, accounting for $47.3 \%$ of the total number of agricultural production and operation personnel, 105.51 million people aged 55 years or above, accounting for $33.6 \%$ of the total number of agricultural production and operation personnel. From the analysis of population structure, children, adults and the elderly need to maintain a certain proportion, so that the overall economic development can be sustained and stable. At present, farming and living in rural areas are mostly elderly people. In recent years, most of the predecessors entered the city to work. The emergence of this situation makes the rural labor force significantly insufficient, so the situation of wasteland appears. Moreover, the decrease of rural youth makes the rural development has not enough reserve population, and the phenomenon that the number of agricultural employees is out of line has appeared. This kind of proportion distribution makes the old-age agriculture and women agriculture appear in rural areas, which is not conducive to the improvement of agricultural productivity, and it is difficult to play the role of increasing farmers' production and income. Therefore, the future development of rural areas is worrying [4-5].

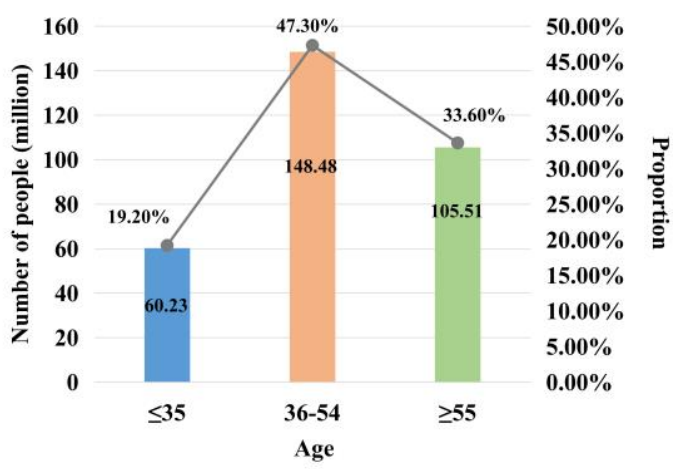

Figure 2. Age characteristics of rural agricultural production and management personnel

\subsection{Problems Caused by Change}

From the above specific changes, this change will bring about two significant problems:

1) land use problems. As far as agricultural production is concerned, land is the foundation. Rational use of land can maximize the utilization rate of land and maximize its value. Therefore, nongcun production will naturally remain in a better state. However, from the current practice of rural land use, a large number of wasteland is enjoying the national land subsidy, but there is no output at all, which causes serious waste of rural resources.

2) The change of rural population structure makes the rural areas lack of young adults and modern farmers in the new era. This situation is not conducive to the mechanization of agricultural production and the development of modernization. Generally speaking, the current changes of land use and population structure in rural areas have brought a lot of inconvenience to the stable, sustainable and efficient development of rural areas, so we must solve specific problems in practice.

\section{COPING STRATEGIES}

From the above specific analysis, the change of rural land and population structure has a very significant impact on rural economic development. Therefore, it is necessary to explore measures to solve specific problems based on the rural modernization development. In this way, the sustainability and stability of rural development can be strengthened, and the overall rural economic strength will be significantly improved. The following is a summary of the practice of coping with the problem strategy [6-7].

\subsection{Speeding Up Rural Land Reform}

In terms of solving the specific problems of rural land, it is very important to emphasize the reform of land system and speed up the land circulation. With the acceleration of urbanization, more and more rural residents settle down and live in the city, and their rural houses and cultivated land have been abandoned. In the past, because the policy does not allow, so the land circulation is more difficult, but at this stage, the policy supports the land circulation, so the relevant departments should do a good job in the propaganda and interpretation of the land circulation policy, so that more people can understand the essence of the land transfer and actively participate in it. In this way, the idle cultivated land can be transferred to the hands of individual agricultural producers or agricultural production enterprises by leasing. Through land transfer, land can be centralized, and land concentration plays a positive role in unified production, management and mechanization. From the specific analysis of land transfer, it has three outstanding advantages: 1) land transferor. In the past, there would be no economic benefits if the land was not cultivated. However, after the land transfer, the land rent could be obtained without self farming, which is beneficial to the land transferor. 2) Land transfer party. In the practice of rural development, it can be found that many farmers want to increase their income through a variety of land, but because of policy reasons, they can't use others' land when they are empty. Under the implementation of the land transfer policy, it obtains enough land by paying rent, which has a significant role in promoting the enthusiasm of producers. 3) For the development of modern agriculture, the practical significance of land circulation is significant. A typical symbol of the development of modern agriculture is mechanization. In the past, due to the dispersion of farmland, mechanization benefits were not significant. With the land circulation, the situation of land concentration is strong, which lays a good foundation for mechanized production. 


\subsection{Strengthening Rural Infrastructure \\ Construction and Emphasizing the Development of Villages and Towns}

From the specific analysis at this stage, it is very necessary to solve the negative impact of rural land and population structure changes, strengthen rural infrastructure construction, and emphasize the construction of villages and towns. From the specific analysis, the reason why the rural young people choose to settle in the city is that, on the one hand, there are more job opportunities in the city, on the other hand, the living environment in the city is better and various facilities are relatively complete. If there are job opportunities and a good living environment in the countryside, many young people will choose to stay in the countryside, because the life in the countryside will be more comfortable. Based on this, we should speed up the construction of rural industry, emphasize the construction of rural infrastructure, and actively construct beautiful countryside. In this way, the attraction of rural areas will be further increased. Many urban youth will choose to return home to live and work, and the rural population structure will be effectively improved. In a word, speeding up the construction of rural infrastructure and emphasizing the development of villages and towns play a positive role in solving the problems brought about by rural population and land change.

\subsection{Do A Good Job in Propaganda and Guidance to Cultivate Farmers in the New Era}

In order to solve the adverse effects of the current rural land and population structure changes, it is also very important to do a good job in propaganda and guidance, and to cultivate farmers in the new era. The so-called farmers in the new era are those who have a certain cultural level and are able to master modern agricultural production technology, equipment and methods [7]. From the reality analysis, many young people think that agricultural production has no future and can't make money, so they will leave their hometown to work in other places. Based on this situation, the relevant units need to do a good job in propaganda, emphasizing scientific and technological production and modern production, so that young people can change their ideas and stay in the countryside to become farmers in the new era. In this way, not only the rural population structure problem can be solved, but also the effect of rural production practice will be significantly improved.

\section{CONCLUSION}

To sum up, rural land and population structure have a great impact on rural economic development. Analyzing the changes of rural land and population structure and discussing the problems caused by the changes are of great practical significance to the development of specific work and the practice of rural economic development.

\section{ACKNOWLEDGMENT}

This work was supported by Huazhong University of Science and Technology.

\section{REFERENCES}

[1] Y. Wang. Institutional interaction and decision making in China's rural development, Journal of Rural Studies, 76 (2020):111-119.DOI: https://doi.org/10.1016/j.jrurstud.2020.04.023

[2] Z. G. Xu, R. Tao. Urbanization, Rural Land System and Social Security in China. China \& World Economy, 012(006) (2004):11-23. DOI : $10.1080 / 00220380701526659$

[3] T. Li, H. Long, Y. Liu, et al. Multi-scale analysis of rural housing land transition under China's rapid urbanization: The case of Bohai Rim. Habitat International, 48 (2015):227-238. DOI : 10.1016/j.habitatint.2015.04.002

[4] Q. F. Zhang, J. Wu. Political dynamics in land commodification: Commodifying rural land development rights in Chengdu, China. Geoforum, 78(JAN) (2015):98109. DOI: $10.1016 /$ j.geoforum.2015.10.001

[5] R. Tu, Y. Li, L. Shen, et alThe prevalence and influencing factors of physical activity and sedentary behaviour in the rural population in China: the Henan Rural Cohort Study. BMJ Open, 9 (2019): e029590. Doi: 10.1136/bmjopen-2019-029590

[6] Y. L. Zhang, G. M. Wang, B. Liu. Theoretical Interpretation, Contradiction Analysis and Breakthrough Path of Implementing the Rural Revitalization Strategy in China. Journal of Tianjin Normal University ( Social Science ) , 03 (2020):52-61.

[7] D. Xie, Z. Q. Li. Urban and Rural Population Migration under the Background of Urbanization and Rural Revitalization: Theory, Contradiction and Outlet. Reform of Economic System, 03 (2020): 39-45 